\title{
THE COMPREHENSION OF DERIVATIONAL MORPHEMES IN EARLY CHILDHOOD: AN EXPERIMENTAL STUDY FOR LITHUANIAN
}

\author{
Ineta Dabašinskienè
}

\begin{abstract}
This paper presents the results of an experiment that explores children's tolerance for word form variation, specifically, it compares preschool-age children's tolerance of word form variants, such as suffixes and prefixes in Lithuanian. The stimuli used in this study were pictures of familiar and unfamiliar animals. It appears that Lithuanian children show great tolerance of word form variation, in particular, children are more tolerant of variation in word endings than onsets. This fact suggests that exposure to a richly inflected language, such as Lithuanian, impacts on children's word-learning strategies.
\end{abstract}

Keywords: language acquisition, morphology, word formation, Lithuanian

\section{Introduction}

Most children, by the time they have reached primary school age, have become highly efficient word learners, and have acquired a number of word learning strategies that help them in finding the possible referents or meanings of new words (Golinkoff et al. 1992). It was observed that children associate novel word forms with unfamiliar categories of objects. This tendency has been called the principle of contrast (Clark 1993, 1995) or the mutual exclusivity (Markman et al. 2003) and states that a child relates the difference in meaning to the difference in form or the unfamiliar object to the new word.

Our study tries to explain to which extent the use of this word learning strategy is influenced by the typology of the language the child is acquiring.

In Baltic and Slavic languages, children are exposed to word form modifications since early childhood. For example, speakers of Lithuanian, a morphologically rich Baltic language, encounter noun morphology varying along the dimensions of two genders (masculine and feminine), two numbers (singular and plural), and seven 
cases (nominative, accusative, genitive, dative, instrumental, locative and vocative). Lithuanian gender categories have quasi-regular correlations with respect to semantic and phonological features of nouns. Thus, most masculine nouns end in -(i)as, -is or -ys, and take the so-called first declension. Most feminine nouns end in -(i) $a$ or $-\dot{e}$, and take the so-called second declension. The first and the second declensions are the most productive declension types. In addition, some feminine nouns end in -is and take the third declension, some masculine nouns end in-us and take the fourth declension, and some masculine and feminine nouns end in-uo and $-\dot{e}$ and take the fifth declension. There are masculine nouns referring to males, e.g., tète 'father', which require masculine adjective-noun and pronominal agreement but in form they resemble feminine nouns and take the second declension.

Lithuanian diminutive morphology is also fairly complex. One very prominent feature of the Lithuanian language is the highly productive formation of diminutives from any noun via one or more suffixes. The most frequent and productive suffixes are the masculine -elis/-èlis, -(i)ukas, -utis, -ytis, -aitis and their feminine

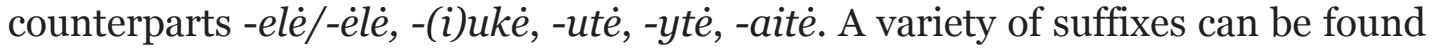
in the formation of diminutives for different lexical semantic groups, and for the majority of nouns at least three or four different suffixes can be attached to the same lemma, e.g., kepur- $\dot{e}$ 'cap-FEM' has diminutive forms kepur-yt-é, kepur-ait- $\dot{e}, k e p u r-$ $\dot{e} l-\dot{e}, k e p u r-i u k-\dot{e}$. The diminutive suffixes are interchangeable with no differences in meaning associated with different suffixes. Note that while the word endings of Lithuanian diminutives are fairly homogeneous (-is and -as for masculine and $-\dot{e}$ for feminine), there is considerable variety in the phonetic structure of the penultimate syllable and, consequently, more overall variety in the structure of diminutives. Moreover, double suffixation, which reinforces the pragmatic effectiveness or the meaning of smallness associated with the diminutive, is common as well, as evidenced by examples such as dal-el-yt-e 'particle-DIM-DIM-FEM', žmog-el-iuk-as 'man-DIM-DIM-MASC', or saul-ut-èl-e 'sun-DIM-DIM-FEM'.

Results from the corpora of spontaneous adult conversations (described in Savickienè 2005, Dabašinskienè 2009) give the following results of the use of diminutives: $3.5 \%-5 \%$ (adult-directed speech or ADS), $53 \%$ (child-directed speech or CDS), $48 \%$ (child speech or CS). It was observed in longitudinal data that young children as well as adults start to use two or three different diminutive suffixes for the same lemma very early and without any difference in meaning, e.g., mešk-iukas, mešk-utè, mešk-ytè from meška 'teddy-bear'; med-ukas, med-utis from medus 'honey' $(1 ; 8)^{1}$; kač-iukas, katin-èlis, kat-ytè from kate் 'cat'; mašin-èlè, mašin-ytè from mašina 'car' (1;9); arbat-èle, arba-tytè from arbata 'tea' (1;10); kišk-utis, kišk-ytis from kiškis 'rabbit'; rank-uté, rank-yte from ranka 'hand' (2;0). These examples clearly contradict Clark's principle of contrast (1995). It follows from the Lithuanian data that a child may perceive two different forms of the same word-its basic meaning and the derived diminutive -, which have two different meanings. According to the principle of contrast, it may be assumed that the speaker will have to relate a difference in form with a difference in meaning (Clark 1995: 394). This tendency, however, is not usual in other languages where children learn diminutive suffixes one after another (Gillis 1997, De Marco 1998).

There is virtually no prefixation in Lithuanian noun derivational morphology. However, Lithuanian verb morphology contains a considerable amount of prefixa- 
tion, with 12 verbal prefixes that alter the meanings of basic verbs. For example, the verb eiti 'to go' can appear in the prefixed forms apeiti, ateiti, ieiti, išeiti, nueiti, paeiti, pareiti, pereiti, praeiti, prieiti, sueiti, and užeiti, all of which express different modifications of the meaning of the basic verb. To the extent that these differences in meaning are rather subtle and involve dimensions such as aspect, time and direction of movement, one can argue that greater amount of prefixation in the language as a whole leads to greater tolerance for word onset modifications in Lithuanian children. This speculation is supported by the data from Wójcik (2000) who reported a case study of a girl's acquisition of Lithuanian (the same corpus is used in Savickienè's (2003) study of the acquisition of noun morphology). In the input directed to the child, $37 \%$ of verbs had prefixed forms (63\% were simplex). The child's speech showed similar rates, with $30 \%$ of verbs containing prefixed forms. Prefixed verbs are documented in the corpus from the first recording at age $1 ; 7$ and have been increasing in frequency, reaching the 50\% rate of prefixation of verb forms, which is comparable to estimates for Lithuanian adult-directed speech ( $57 \%$ simplex and 53\% prefixed verb forms).

Thus, children are familiar with the prefixed and suffixed word formation strategies since the early period of language acquisition, with only one difference, that is, prefixes are used mostly with verbs and suffixes are used with nouns.

As it was stated above, some first language acquisition studies have shown that children show a strong preference to associate novel word forms with unfamiliar categories of objects. When presented with novel word forms in a forced-choice comprehension test, children readily choose novel objects as opposed to objects with familiar names often described as a "taxonomic response" (Bruening, Brooks 2006). This explanation, though rather robust under controlled conditions of novelty, fails to explain or justify the pervasive use of diminutives in CDS, especially in Baltic, Slavic and Romance languages (see Savickienè 2003, Savickienè, Dressler 2007, Savickienė et al. 2007, Wójcik 1994, Kempe et al. 2007, Olmsted 1994) the speakers of which repeatedly use different morphological derivations to refer to the same objects.

\section{Method}

Thirty-nine monolingual children (mean age 4;5, range 2;2-6;8, 19 boys and 20 girls) were tested at several day-care centers, schools and at home in Kaunas, Lithuania.

\subsection{Material and design}

The present research uses a word-learning protocol in which a word-form modification is introduced as a second label of an object. The experiment introduces two contrasting changes in word form involving the same word stem. In one condition the suffix introduces a change to the end of the word and in the other condition the prefix changes the onset of the word. The visual stimuli were $13 \times 18 \mathrm{~mm}$ pictures of animals, which were collected from nature albums, websites, and other sources. The pictures were arranged into two folders and the material was used to carry out 18 trials, 2 training and 16 test trials. Half of the trials contained pictures of familiar 
animals while the other half contained pictures of novel animals. Images of familiar animals were carefully selected to represent objects and their names already known by pre-school children. The novel animals looked unfamiliar to children because of their non-European appearance. Half of the trials involved bi-syllabic animal names and half-tri-syllabic names. Each trial had an introductory page with a single picture of an animal while a second page contained the first image along with the image of a different animal (i.e., two novel animals or two familiar animals). The introductory page served the purpose of naming the animal by its simplex form, by saying, for example, 'I call this animal a goat'. The test page was used for the forced-choice probe described above. The 18 trials comprised two initial trials to ensure comprehension of the instructions and 16 test trials. The test trials involved the manipulation of two factors: noun type (novel versus familiar) and position of word form modification (beginning versus end of a word).

Half of the nouns were feminine and half were masculine, half of the nouns of each gender had two syllables and the other half had three syllables. The words selected for each stimulus pair were of the same gender and declension class. Two word form modifications to the nouns were selected: (1) diminutive suffixes (-(i)ukas for masculine and -yte for feminine nouns) and (2) addition of the invented prefix $p a$ - (for the example, see Table 1). The prefix $p a$ - is very often used with verbs, but not with nouns. This prefix was chosen to create natural-sounding Lithuanian stimuli and to avoid allophonic variation in word onsets, even though the formation $p a$-plus noun is ungrammatical ${ }^{2}$. There is no such word as pavarle in Lithuanian, but the word varle 'frog' exists and the prefix is added to create a novel form.

Position of word form modification was counterbalanced across trials (beginning versus end).

Table 1. An example of stimuli

\begin{tabular}{|l|c|c|}
\hline Stimuli Conditions & Words & Novel words \\
\hline Simplex & ožys 'goat' & lodine \\
\hline Target end change (diminutive suffix) & ož-iukas 'goat-DIM' & lodin-yte \\
\hline Target beginning change (prefix pa-) & pa-ožys & pa-lodine \\
\hline Alternate end change & rykl-iukas 'shark-DIM' & gokad-yte \\
\hline Alternate beginning change & pa-ryklys & pa-gokade \\
\hline
\end{tabular}

\subsection{Procedure}

Each child was tested individually in a single session of approximately 10 to 15 minutes duration. The children were invited to play a game of pointing at the picture with a different animal. They were told that some of the animals look very strange and have unfamiliar names and that they should try to guess which animal might be called by the given name.

Two training trials were used to ensure understanding of the task. Each trial began with the introduction of the first animal picture using the simplex form of the animal name (page one). An experimenter would make a statement (Čia yra ožys 'this is a goat'), and a child was asked to repeat the word. The second page was an experimental one: the animal from the first page was shown and a new picture

\footnotetext{
2 The prefix derivation in nouns is only possible together with inflectional change. The prefix addition to a noun changes not only its inflection, but also the meaning of the new derived noun, for example, lang-as 'window-MAsc' and pa-lang-é 'windowsill-FEM'.
} 
was added. The second page could contain either two familiar or two unfamiliar animals. A suffix or prefix was attached to the animal names. The child was asked to point at the animal in question (Parodyk man, kur yra pa-ožys? 'Show me where a $p a$-goat is?'). The same order was followed while working with unfamiliar animals and novel words. The children were instructed to point at a required picture, and their responses were recorded and coded. In the case of wrong responses (i.e., pointing) the children were not corrected by the experimenter.

Children's ability to select the right animal during the experimental trials was measured according to the following parameters: word form modification (beginning vs. end), the structure of the word (two-syllable words vs. three-syllable) and noun familiarity (familiar vs. novel). Age and gender of a child was taken into consideration as well.

\section{Results and discussion}

An ANOVA was used for the data analysis. The preliminary analyses of the experiment indicated no significant difference in accuracy of performing the task for boys and girls (81.7\% correct for boys, $82.7 \%$ for girls), and child age was not correlated with the results of accuracy. Preliminary analysis also failed to show a significant difference in accuracy for bi-syllabic versus tri-syllabic nouns (84.8\% correct for bi-syllabic nouns, $79.7 \%$ correct for tri-syllabic nouns). Preliminary analyses showed significantly higher accuracy for feminine nouns than for masculine nouns $(85.5 \%$ correct for feminine nouns, $78.9 \%$ correct for masculine nouns). Better performance with feminine nouns was not anticipated, as there is a greater number of masculine nouns in Lithuanian (the masculine gender is unmarked), and indicates that for our stimuli (both familiar and novel nouns), the feminine word forms were easier for the children to remember than their masculine counterparts.

The Lithuanian children were significantly more accurate with suffix derivation than variation involving prefixation (85.5\% vs. $78.9 \%)$, and more accurate with familiar than novel nouns ( $87.9 \%$ vs. $76.6 \%)$. The influence of position suggests that Lithuanian children were more sensitive to diminutive derivations as final word form modification than prefix derivation as initial word form modification. The influence of final position, however, could have been expected because of a productive Lithuanian diminutive derivation, as opposed to a non-productive modification of word onset position in the sense that the onset modification was ungrammatical. Lithuanian diminutives tend to be stressed suffixes, which makes them more acoustically salient than other parts of the word.

Another significant factor seems to be familiarity. The children were making more errors in novel nouns than in familiar ones. There was also a tendency noticed to the effect that children make more errors in three-syllable words than in two-syllable words. This holds for both familiar and novel nouns even though the results are not statistically significant. It may perhaps suggest that longer words are more difficult to remember.

One more conclusion follows from the data analysis, and this is that the children did better with the diminutive nouns than with $p a$-prefixed nouns when they hear familiar words. For novel nouns, the children are not better with the diminutives. 
The interesting difference between these results and English data is that American children show a strong preference for picking a "different" picture throughout the task (Bruening, Brooks 2006). That is, they do not like morphological variation at all, and tend to select the new picture when they hear the new word form. The Lithuanian children do not show this bias and are equally good at trials where they "should" pick the same picture and when they "should" pick a different picture. This might be explained by the typological differences of the two languages.

In his famous paper on "operating principles" that guide early language learners, Slobin (1973) proposes that the ends of the words are more salient than the beginnings, therefore the former are easier for acquisition. In the case of morphologically rich languages young children encounter modifications of word final position all the time. Starting with a very early period of language acquisition, Lithuanian children hear words that consist of two elements, i.e. "word = stem + ending", whereas English-speaking children (English is referred to as a "poor morphology language") get familiarized with a word structure "word = stem". This word structure is acquired early; therefore, children can identify the modifications of word final position quite easily. Similar results were also provided by research on second language acquisition (Ellis 1997) where the operating principle "pay attention to word end" (Slobin 1973) was indicated as very helpful in the process of language acquisition.

Word learning strategies are influenced by the typology of the language. The cues to systematic features of a language are available in the speech input directed to children and provide children with information about the typology of the language as a whole. Thus, language-learning strategies are shaped by the child's experience of the language.
Abbreviations
DIM diminutive
FEM feminine
MASC masculine

\section{References}

Bruening, Paul; Brooks, Patricia 2006. Children's tolerance of word-form variation. - Poster presented at Boston International Conference for the Study of Child Language, July 2006.

Clark, Eve 1993. The Lexicon in Acquisition. Cambridge: Cambridge University Press.

Clark, Eve 1995. Later lexical development and word formation. - P. Fletcher, B. MacWhinney (Eds.). The Handbook of the Child Language. Oxford: Blackwell, 393-412.

Dabašinskienė, Ineta 2009. Šnekamosios lietuvių kalbos morfologinės ypatybès. [Morphological features of spoken Lithuanian]. - Acta Linguistica Lituanica, 60, 1-16.

De Marco, Anna 1998. The acquisition of diminutives in Italian. Studies in the acquisition of number and diminutive marking. - S. Gillis (Ed.). Antwerp Papers in Linguistics, 95, 175-192.

Ellis, Rod 1997. Second Language Acquisition. Oxford Introduction to Language Study ELT. Oxford: Oxford University Press.

Gillis, Steven 1997. The acquisition of diminutives in Dutch. - W. U. Dressler (Ed.). Studies in Pre- and Protomorphology. Vienna: Österreichische Akademic der Wissenschaften, 165-179. 
Golinkoff, M. Roberta; Hirsh-Pasek, Kathy; Bailey, Lisa; Wenger, Neil R. 1992. Young children and adults use lexical principles to learn new nouns. - Developmental Psychology, 28 (1), 99-108.

Markman, M. Ellen; Wasow, L. Judith; Hansen, B. Mikkel 2003. Use of the mutual exclusivity assumption by young word learners. - Cognitive Psychology, 47, 241-275. doi:10.1016/ So010-0285(03)00034-3

Kempe, Vera; Brooks, Patricia; Mironova, Natalija; Pershukova, Angelina; Fedorova, Olga 2007. Playing with word endings: Exploring effects of morphological variation in the learning of Russian noun inflections. - British Journal of Developmental Psychology, $25,55-77$.

Olmsted, Hugh 1994. Diminutive morphology of Russian children: A simplified subset of nominal declension in language acquisition. - Charles E. Gribble, et al. (Eds.). Alexander Lipson: In Memoriam. Columbus, OH: Slavica Inc., 165-209.

Savickienè, Ineta 2003. The Acquisition of Lithuanian Noun Morphology. Wien: Verlag der Österreichischen Akademie der Wissenschaften.

Savickiené, Ineta 2005. Morfopragmatika: deminutyvų vartojimas dabartinëje lietuvių kalboje. [Morphopragmatics: the use of diminutives in Modern Lithuanian.] - Kalbotyra, 54 (1), 91-100.

Savickiené, Ineta; Dressler, U. Wolfgang (Eds.) 2007. The Acquisition of Diminutives: A Cross-Linguistic Perspective. Language Acquisition and Language Disorders, 43. Amsterdam, Philadelphia: John Benjamins.

Savickienė, Ineta; Dressler, U. Wolfgang; Barcza, Virag; Bodor, Peter; Ketrez, Nihan; KoreckyKröll, Katharina; Palmović, Marian; Stephany, Ursula; Thomadaki, Evangelina 2007. Diminutives as pioneers of derivational and inflectional development - a crosslinguistic perspective. - Sabine Laaha, Steven Gillis (Eds.). Antwerp Papers in Linguistics, 112. Antwerp: Universiteit Antwerpen, 81-92.

Slobin, I. Dan 1973. Cognitive prerequisites for the development of grammar. - Ch. A. Ferguson, D. I. Slobin (Eds.). Studies of Child Language Development. New York etc.: Holt, Rinehart, Winston, Inc., 175-208.

Wójcik, Paweł 1994. Some characteristic features of Lithuanian baby talk. - Linguistica Baltica, 3, 71-86.

Wójcik, Paweł 2000. The Acquisition of Lithuanian Verb Morphology: A Case Study. Kraków: Quartis.

Ineta Dabašinskienè (Regional Studies Department, Vytautas Magnus University, Lithuania). Her research interests cover interdisciplinary areas such as socio- and psycholinguistics, especially first and second language acquisition, normal and impaired language development, language use and variation.

i.dabasinskiene@pmdf.vdu.It 


\section{TULETUSMORFEEMIDE OMANDAMINE VARAJASES LAPSEEAS: LEEDU EKSPERIMENT}

Ineta Dabašinskienè

Vytautas Magnuse Ülikool

Artikkel annab ülevaate eksperimendist, mille abil vaadeldi, kuidas suhtuvad eelkooliealised leedu keelt omandavad lapsed sõnavormi eri osade ehk sufiksite ja prefiksite varieerumisse. Katse stiimuliks olid pildid, millel oli kujutatud tuttavaid ja võõraid loomi, nende loomade kohta kasutati sõnavorme, milles varieerus kas sõna algus (sõnale lisati prefiks) või lõpp (deminutiivsufiks -yt või -ukas). Eesmärk oli teha kindlaks: kas lapsed peavad sufiksiga (deminutiivsufiks) ja prefiksiga vorme uuteks sõnadeks või mitte (prefiks $p a-$, mida tavaliselt kasutatakse koos tegusõnadega, liideti siinses katses nimisõnadele); kas laste oskus neid sõnu korrektselt kasutada on vastuolus väitega, et lapsed eelistavad uusi sõnu kasutada uute objektide tähistamiseks ning kuidas suhtuvad leedu keelt omandavad lapsed sõna lõpu ja sõna alguse varieerumisse. Eksperimendis osales 39 eelkooliealist last vanuses 2;2-6;8 (keskmine vanus 4;5). Tulemustest selgus, et lapsed aktsepteerivad sõnavormis lõpu varieerumist tunduvalt enam kui sõna algusosa varieerumist. Seega mõjutab asjaolu, et leedu keel on rikka muutemorfoloogiaga keel, kus grammatiliselt oluline info on sõnavormi lõpus, laste keeleomandamisstrateegiat.

Võtmesõnad: keeleomandamine, morfoloogia, sõnamoodustus, leedu keel 